\title{
Przemysł ziemiański w Królestwie Polskim w latach 1879-1913
}

Problem uprzemysłowienia majątków ziemskich w Królestwie Polskim na przełomie XIX i XX w. w dotychczasowej literaturze historycznej nie został opracowany. Autor na podstawie spisów zakładów przemysłowych z lat 1879, 1900, 1904 i 1913 podjął próbę statystycznego ujęcia problemu rozwoju oraz rozmieszczenia przemysłu ziemiańskiego w Królestwie Polskim.

\section{Rozwój przemysłu ziemiańskiego w latach 1879-1913}

W latach 1879-1913 nastąpił znaczący rozwój przemysłu w majątkach ziemiańskich w Królestwie Polskim. Liczba zakładów zwiększyła się w latach 1879-1904 o ponad 66\% (z 336 do 558), a następnie do 1913 r. obniżyła się do 501 firm. Wartość produkcji przez cały okres 1879-1913 systematycznie rosła - z 8,6 mln rb do 30,9 mln rb, łącznie ponad trzy razy. Liczba zatrudnionych robotników w zakładach ziemiańskich zwiększyła się o ponad 48\% (z 11200 osób do 16 643). Moc maszyn i urządzeń energetycznych w tym czasie wzrosła ponad 21 razy (tab. 1).

Tabela 1. Rozwój przemysłu ziemiańskiego (wszystkie gałęzie) w Królestwie Polskim w latach 1879-1913

\begin{tabular}{|c|c|c|c|c|c|c|c|c|}
\hline Lata & $\begin{array}{c}\text { Liczba } \\
\text { firm }\end{array}$ & $\begin{array}{c}\text { Udział } \\
(\mathrm{w} \%)\end{array}$ & $\begin{array}{c}\text { Wartość produkcji } \\
(\mathrm{w} \text { tys. } \mathrm{rb})\end{array}$ & $\begin{array}{c}\text { Udział } \\
(\mathrm{w} \%)\end{array}$ & $\begin{array}{c}\text { Liczba } \\
\text { robotników }\end{array}$ & $\begin{array}{c}\text { Udział } \\
(\mathrm{w} \%)\end{array}$ & $\begin{array}{c}\text { Moc } \\
(\mathrm{w} \mathrm{KM})\end{array}$ & $\begin{array}{c}\text { Udział } \\
(\mathrm{w} \%)\end{array}$ \\
\hline 1879 & 336 & 100,0 & 8676 & 100,0 & 11200 & 100,0 & 837 & 100,0 \\
1900 & 471 & 140,2 & 22740 & 262,1 & 13496 & 124,5 & &. \\
1904 & 558 & 166,1 & 27880 & 321,3 & 15161 & 135,3 & 7075 & 845,2 \\
1913 & 501 & 149,1 & 30946 & 356,6 & 16643 & 148,6 & 18172 & 2171,1 \\
\hline
\end{tabular}

Źródło: (Puś 2013). 
Tempo rozwoju przemysłu ziemiańskiego było stosunkowo niskie w porównaniu z dynamiką rozwoju całego przemysłu Królestwa Polskiego w latach 1879-1913. W okresie tych 34 lat liczba przedsiębiorstw przemysłowych zwiększyła się ponad dwukrotnie (z 1922 do 3940 zakładów). Wartość produkcji całego przemysłu wzrosła niemal ośmiokrotnie (z 116,6 mln rb do $897,6 \mathrm{mln} \mathrm{rb}$ ), a liczba zatrudnionych robotników ponad 4,5 razy (z 90558 do 412437 osób). Moc maszyn i urządzeń energetycznych zwiększyła się ponad 23 razy. Powyższe dane świadczą o szybkim rozwoju przemysłu i o zdecydowanym postępie w mechanizacji produkcji (Puś 2013: 9, tab. 1).

Ważną sprawą jest porównanie udziału przemysłu ziemiańskiego w ogólnej liczbie przedsiębiorstw, globalnej wartości produkcji, ogólnym zatrudnieniu oraz całej mocy energetycznej przemysłu Królestwa Polskiego.

Tabela 2. Udział zakładów ziemiańskich w całym przemyśle Królestwa Polskiego w latach 1879-1913

\begin{tabular}{|c|c|r|r|r|r|r|r|r|r|}
\hline Lata & CP i Z & $\begin{array}{c}\text { Liczba } \\
\text { firm }\end{array}$ & $\begin{array}{c}\text { Udział } \\
(\mathrm{w} \%)\end{array}$ & $\begin{array}{c}\text { Wartość } \\
\text { produkcji } \\
\text { (w tys. rb) }\end{array}$ & $\begin{array}{c}\text { Udział } \\
(\mathrm{w} \%)\end{array}$ & $\begin{array}{c}\text { Liczba } \\
\text { robotników }\end{array}$ & $\begin{array}{c}\text { Udział } \\
(\mathrm{w} \%)\end{array}$ & $\begin{array}{c}\text { Moc } \\
(\mathrm{w} \mathrm{KM})\end{array}$ & $\begin{array}{c}\text { Udział } \\
(\mathrm{w} \%)\end{array}$ \\
\hline \multirow{2}{*}{1879} & $\mathrm{CP}$ & 1922 & 100,0 & 116609 & 100,0 & 90558 & 100,0 & 17432 & 100,0 \\
& $\mathrm{Z}$ & 336 & 17,4 & 8676 & 7,4 & 11200 & 12,3 & 837 & 4,8 \\
\hline \multirow{2}{*}{1900} & $\mathrm{CP}$ & 2761 & 100,0 & 405375 & 100,0 & 254131 & 100,0 & 200000 & 100,0 \\
& $\mathrm{Z}$ & 471 & 17,0 & 22740 & 5,6 & 13496 & 5,3 &. &. \\
\hline \multirow{2}{*}{1904} & $\mathrm{CP}$ & 3592 & 100,0 & 596187 & 100,0 & 324702 & 100,0 & 217373 & 100,0 \\
& $\mathrm{Z}$ & 558 & 15,5 & 27880 & 4,6 & 15161 & 4,6 & 7075 & 3,2 \\
\hline \multirow{2}{*}{1913} & $\mathrm{CP}$ & 3940 & 100,0 & 897664 & 100,0 & 412437 & 100,0 & 406186 & 100,0 \\
& $\mathrm{Z}$ & 501 & 12,7 & 30946 & 3,4 & 16643 & 4,0 & 18172 & 4,4 \\
\hline
\end{tabular}

Objaśnienia: CP - cały przemysł Królestwa Polskiego; Z - przemysł ziemiański. Źródło: jak w tab. 1.

Dane statystyczne z tabeli 2 wskazuja, że udział przemysłu ziemiańskiego w ogólnej liczbie przedsiębiorstw i zakładów przemysłowych w Królestwie Polskim w całym badanym okresie był stosunkowo wysoki, wahał się bowiem od 17,4\% w 1900 r. do 12,7\%. Z kolei w globalnej wartości produkcji przemysłu Królestwa Polskiego udział firm ziemiańskich był niski i systematycznie malał (od 7,4\% w 1879 r. do 3,4\% w 1913 r.). Podobnie w ogólnym zatrudnieniu w przemyśle Królestwa Polskiego udział ten w latach 1879-1913 zdecydowanie zmniejszył się z 12,3\% do 4\%. Stosunkowo wysoki udział w zatrudnieniu w 1879 r. świadczy od zacofaniu technicznym i technologicznym firm ziemiańskich, wśród których większość nie była zmechanizowana, a produkcja oparta była na pracy ręcznej. Udział przemysłu ziemiańskiego w ogólnej mocy energetycznej w całym przemyśle Królestwa Polskiego także był niski i wahał się od 4,8\% w 1879 r. do 4,4\% w 1913 r. (tab. 2). 


\section{Rozmieszczenie przemysłu ziemiańskiego w latach 1879-1913}

Strukturę przestrzenną przemysłu ziemiańskiego przedstawiono w czterech przekrojach chronologicznych za lata 1879, 1900, 1904 i 1913 z podziałem na 10 guberni Królestwa Polskiego.

Tabela 3. Rozmieszczenie przemysłu ziemiańskiego w Królestwie Polskim w 1879 r.

\begin{tabular}{|l|c|c|c|r|r|r|}
\hline Gubernie & Liczba firm & $\begin{array}{c}\text { Udział } \\
\text { (w \%) }\end{array}$ & $\begin{array}{c}\text { Wartość produkcji } \\
\text { (w tys. rb) }\end{array}$ & $\begin{array}{r}\text { Udział } \\
\text { (w \%) }\end{array}$ & $\begin{array}{r}\text { Liczba } \\
\text { robotników }\end{array}$ & $\begin{array}{c}\text { Udział } \\
\text { (w \%) }\end{array}$ \\
\hline Kaliska & 26 & 7,8 & 1580 & 20,8 & 818 & 7,4 \\
Kielecka & 30 & 8,9 & 312 & 4,1 & 666 & 6,0 \\
Lubelska & 87 & 25,9 & 1601 & 21,1 & 1300 & 11,7 \\
Łomżyńska & 27 & 8,0 & 309 & 4,1 & 210 & 1,9 \\
Piotrkowska & 23 & 6,8 & 1145 & 15,2 & 1709 & 15,4 \\
Płocka & 18 & 5,4 & 508 & 6,7 & 695 & 6,3 \\
Radomska & 48 & 14,4 & 616 & 8,1 & 3157 & 28,4 \\
Siedlecka & 51 & 15,3 & 834 & 11,0 & 1018 & 9,2 \\
Suwalska & 9 & 2,7 & 85 & 1,1 & 55 & 0,5 \\
Warszawska & 16 & 4,8 & 590 & 7,8 & 1468 & 13,2 \\
\hline Królestwo & 335 & 100 & 7580 & 100 & 11096 & 100 \\
Polskie & & & & & & \\
\hline
\end{tabular}

Źródło: jak w tab. 1.

W strukturze przestrzennej przemysłu ziemiańskiego w Królestwie Polskim w 1879 r. pierwszoplanową rolę odgrywała gubernia lubelska, która miała najwyższy udział w ogólnej liczbie zakładów, skupiając 25,9\% ogółu firm, podobnie w globalnej wartości produkcji jej udział zdecydowanie przekraczał 21\%, natomiast w ogólnej liczbie robotników zajmowała dopiero czwarte miejsce, zatrudniając $11,7 \%$ osób pracujących w całym przemyśle ziemiańskim. Drugą pozycję w ogólnej liczbie firm zajmowała gubernia siedlecka, gdzie funkcjonowało 15,3\% ogółu zakładów ziemiańskich. Jednak w globalnej wartości produkcji udział guberni siedleckiej sięgający $11,0 \%$ plasował ją na czwartym miejscu, natomiast w zatrudnieniu zakłady ziemiańskie $\mathrm{w}$ tej guberni skupiały 9,2\% robotników, zajmując piątą pozycję. Pod względem udziału w globalnej produkcji drugie miejsce zajmowała najbardziej uprzemysłowiona w Królestwie Polskim gubernia kaliska, skupiając 20,8\% wartości produkcji przemysłu ziemiańskiego, w zatrudnieniu firmy ziemiańskie tej guberni zajmowały dalszą pozycję z udziałem $7,4 \%$, a w ogólnej liczbie zakładów jedynie 7,8\%, co dawało piąte miejsce. $\mathrm{W}$ ogólnym zatrudnieniu $\mathrm{w}$ przemyśle ziemiańskim pierwszą pozycję zajmowała gubernia radomska, skupiając $28,4 \%$ ogółu robotników, udział tej guberni w globalnej produkcji sięgał 8,1\%, co dawało dopiero piąte miejsce w skali Królestwa Polskiego, natomiast 
w ogólnej liczbie firm zajmowała ona trzecią pozycję z udziałem 14,4\%. Wśród pozostałych guberni na uwagę zasługuje gubernia piotrkowska, która mimo niewielkiej liczby zakładów ziemiańskich skupiała 15,2\% globalnej wartości produkcji i 15,4\% ogólnego zatrudnienia oraz gubernia warszawska, która skupiała 13,2\% ogólnej liczby robotników i 7,8\% produkcji (tab. 3).

Tabela 4. Rozmieszczenie przemysłu ziemiańskiego w Królestwie Polskim w 1900 r.

\begin{tabular}{|l|c|c|c|r|r|r|}
\hline Gubernie & Liczba firm & $\begin{array}{c}\text { Udział } \\
\text { (w \%) }\end{array}$ & $\begin{array}{c}\text { Wartość produkcji } \\
\text { w tys. rb }\end{array}$ & $\begin{array}{r}\text { Udział } \\
(\mathrm{w} \%)\end{array}$ & $\begin{array}{r}\text { Liczba } \\
\text { robotników }\end{array}$ & $\begin{array}{r}\text { Udział } \\
\text { (w \%) }\end{array}$ \\
\hline Kaliska & 50 & 10,6 & 2677 & 11,8 & 1217 & 9,0 \\
Kielecka & 40 & 8,5 & 806 & 3,5 & 584 & 4,3 \\
Lubelska & 57 & 12,1 & 5897 & 25,9 & 2814 & 20,9 \\
Łomżyńska & 42 & 8,9 & 936 & 4,1 & 660 & 4,9 \\
Piotrkowska & 57 & 12,1 & 2842 & 12,6 & 1900 & 14,1 \\
Płocka & 14 & 3,0 & 1048 & 4,6 & 465 & 3,4 \\
Radomska & 56 & 11,9 & 3422 & 15,0 & 2610 & 19,4 \\
Siedlecka & 66 & 14,0 & 2200 & 9,7 & 1659 & 12,3 \\
Suwalska & 21 & 4,5 & 414 & 1,8 & 195 & 1,4 \\
Warszawska & 68 & 14,4 & 2498 & 11,0 & 1392 & 10,3 \\
\hline Królestwo & 471 & 100 & 2740 & 100 & 13496 & 100 \\
Polskie & & & & & \\
\hline
\end{tabular}

Źródło: jak w tab. 1.

W 1900 r., w stosunku do struktury przestrzennej z 1879 r., nastąpiły dość istotne zmiany. Gubernia lubelska umocniła swoją pierwszą pozycję w globalnej wartości produkcji, a jej udział wzrósł z 21,1\% do 25,9\%. W ogólnym zatrudnieniu w przemyśle ziemiańskim gubernia ta również zajęła pierwsze miejsce, a jej udział zwiększył się zdecydowanie z 11,7\% do 20,9\%. Tak więc gubernia lubelska w 1900 r. skupiała ponad czwarta część produkcji oraz ponad piątą część ogólnej liczby robotników w całym przemyśle ziemiańskim Królestwa Polskiego. Drugą pozycję zajmowała gubernia radomska, której udział w globalnej wartości produkcji $\mathrm{w}$ latach 1879-1900 wzrósł z 8,1\% do 15\%, natomiast wskaźnik zatrudnienia (obszar ten zajmował w 1900 r. w tej kategorii również drugie miejsce) wyraźnie się obniżył (z 28,4\% do 19,4\%). Trzecią pozycję, tak pod względem udziału w produkcji, jak i zatrudnieniu zajmowała gubernia piotrkowska, ale w stosunku do 1879 r. wskaźniki jej udziału wyraźnie się obniżyły - w globalnej wartości produkcji z 15,2\% do 12,6\%, a w ogólnej liczbie robotników z 15,4\% do 14,1\%. Kolejne, czwarte miejsce w globalnej wartości produkcji zajęła gubernia kaliska, skupiając 11,8\% produkcji przemysłu ziemiańskiego w Królestwie Polskim, jednak jej udział w stosunku do 1879 r. obniżył się o 9\%. Piątą pozycję, podobnie jak w 1879 r., w produkcji zajęła gubernia warszawska z udziałem $11 \%$, co oznaczało 
wzrost o 3,2\%, z kolei w ogólnym zatrudnieniu udział tej guberni obniżył się z 13,2\% do 10,3\%. Wśród pozostałych guberni na uwagę zasługuje jeszcze gubernia siedlecka, której udział w globalnej wartości produkcji w latach 1879-1900 spadł z 11,0\% do 9,7\%, natomiast wskaźnik zatrudnienia wzrósł z 9,2\% do 12,3\%. Najniższy udział w produkcji oraz w ogólnej liczbie robotników miały, podobnie jak w 1879 r., trzy gubernie: suwalska, kielecka i płocka (tab. 3 i 4 ).

Tabela 5. Rozmieszczenie przemysłu ziemiańskiego w Królestwie Polskim w 1904 r.

\begin{tabular}{|l|c|r|c|r|r|r|}
\hline Gubernie & Liczba firm & $\begin{array}{r}\text { Udział } \\
(\mathrm{w} \%)\end{array}$ & $\begin{array}{c}\text { Wartość produkcji } \\
\text { (w tys. rb) }\end{array}$ & $\begin{array}{r}\text { Udział } \\
(\mathrm{w} \%)\end{array}$ & $\begin{array}{r}\text { Liczba } \\
\text { robotników }\end{array}$ & $\begin{array}{r}\text { Udział } \\
(\mathrm{w} \%)\end{array}$ \\
\hline Kaliska & 63 & 11,3 & 2419 & 8,9 & 1076 & 7,1 \\
Kielecka & 36 & 6,4 & 798 & 2,9 & 569 & 3,8 \\
Lubelska & 82 & 14,7 & 6922 & 25,4 & 2584 & 17,0 \\
Łomżyńska & 38 & 6,8 & 1620 & 5,9 & 936 & 6,2 \\
Piotrkowska & 72 & 12,9 & 5040 & 18,5 & 2758 & 18,2 \\
Płocka & 21 & 3,8 & 1880 & 6,9 & 764 & 5,0 \\
Radomska & 80 & 14,4 & 2221 & 8,2 & 3024 & 19,9 \\
Siedlecka & 67 & 12,0 & 2920 & 10,7 & 1849 & 12,2 \\
Suwalska & 21 & 3,8 & 285 & 1,0 & 178 & 1,2 \\
Warszawska & 78 & 13,9 & 3174 & 11,6 & 1424 & 9,4 \\
\hline Królestwo & 558 & 100 & 27279 & 100 & 15161 & 100 \\
Polskie & & & & & & \\
\hline
\end{tabular}

Źródło: jak w tab. 1.

W 1904 r. gubernia lubelska, podobnie jak w poprzednich przekrojach chronologicznych, utrzymała pierwsze miejsce w produkcji, skupiając 25,4\% globalnej wartości produkcji przemysłu ziemiańskiego w Królestwie Polskim. Natomiast w ogólnym zatrudnieniu w stosunku do $1900 \mathrm{r}$. zakłady ziemiańskie tej guberni obniżyły swój udział z 20,9\% do 17\% i zajęły trzecią pozycję. Z kolei w ogólnej liczbie zakładów gubernia lubelska zwiększyła swój udział z 12,1\% w 1900 r. do 14,7\% w 1904 r. i zajęła pierwsze miejsce. Drugą pozycję w produkcji przemysłu ziemiańskiego w 1904 r. zajmowała gubernia piotrkowska, skupiając 18,5\% globalnej wartości produkcji (w stosunku do $1900 \mathrm{r}$. był to wzrost o prawie 6\%). Podobnie w ogólnej liczbie robotników gubernia piotrkowska zajmowała drugie miejsce $\mathrm{z}$ udziałem $18,2 \%$, w stosunku do $1900 \mathrm{r}$. nastąpił wzrost o ponad $4 \%$. Trzecią pozycję w produkcji w $1904 \mathrm{r}$. zajęła gubernia warszawska, skupiając 11,6\% globalnej wartości produkcji przemysłu ziemiańskiego. Z kolei gubernia radomska, która w 1900 r. zajmowała w produkcji drugą pozycję z udziałem $15 \%$, spadła na szóste miejsce, skupiając 8,2\% ogólnej wartości produkcji. Gubernia ta jednak pod względem zatrudnienia zajęła w 1904 r. pierwszą pozycję, a jej udział wynosił 19,9\% ogółu robotników 
przemysłu ziemiańskiego. Wzrost udziału w produkcji należy również odnotować w guberni siedleckiej w stosunku do 1900 r. (z 9,7\% do 10,7\%), natomiast pod względem zatrudnienia gubernia ta utrzymała czwarte miejsce $\mathrm{z}$ udziałem $12,2 \%$. Najniższy udział, tak w produkcji, jak i w zatrudnieniu, miały - podobnie jak w poprzednich latach - gubernie: kielecka i suwalska (tab. 4 i 5).

Tabela 6. Rozmieszczenie przemysłu ziemiańskiego w Królestwie Polskim w 1913 r.

\begin{tabular}{|l|c|c|c|r|r|r|}
\hline Gubernie & Liczba firm & $\begin{array}{c}\text { Udział } \\
(\mathrm{w} \%)\end{array}$ & $\begin{array}{c}\text { Wartość produkcji } \\
\text { (w tys. rb) }\end{array}$ & $\begin{array}{r}\text { Udział } \\
(\mathrm{w} \%)\end{array}$ & $\begin{array}{r}\text { Liczba } \\
\text { robotników }\end{array}$ & $\begin{array}{r}\text { Udział } \\
(\mathrm{w} \%)\end{array}$ \\
\hline Kaliska & 48 & 9,6 & 2702 & 8,7 & 1081 & 6,5 \\
Kielecka & 32 & 6,4 & 873 & 2,8 & 522 & 3,1 \\
Lubelska & 88 & 17,6 & 8277 & 26,8 & 3657 & 21,9 \\
Łomżyńska & 38 & 7,6 & 1790 & 5,8 & 783 & 4,7 \\
Piotrkowska & 45 & 9,0 & 4588 & 14,9 & 2741 & 16,6 \\
Płocka & 22 & 4,4 & 1535 & 4,9 & 674 & 4,0 \\
Radomska & 51 & 10,1 & 2703 & 8,7 & 2249 & 13,6 \\
Siedlecka & 66 & 13,2 & 3647 & 11,8 & 1325 & 8,0 \\
Suwalska & 24 & 4.8 & 562 & 1,8 & 359 & 2,1 \\
Warszawska & 87 & 17,3 & 4269 & 13,8 & 3252 & 19,5 \\
\hline Królestwo & 501 & 100 & 30946 & 100 & 16643 & 100 \\
Polskie & & & & & \\
\hline
\end{tabular}

Źródło: jak w tab. 1.

W strukturze przestrzennej przemysłu ziemiańskiego w Królestwie Polskim w 1913 r. przewaga guberni lubelskiej nad pozostałymi została utrwalona. Funkcjonowało w niej najwięcej zakładów ziemiańskich, co stanowiło 17,6\% ogólnej liczby firm. Udział w globalnej wartości produkcji w stosunku do 1904 r. zwiększył się z 25,4\% do 26,8\%, w zatrudnieniu z $17 \%$ do 21,9\%. Drugą pozycję pod względem udziału w ogólnej liczbie zakładów zajmowała gubernia warszawska -17,3\%. Gubernia ta zajmowała także drugie miejsce $\mathrm{w}$ globalnym zatrudnieniu $\mathrm{w}$ przemyśle ziemiańskim, skupiając 19,5\% ogółu robotników. Natomiast w produkcji z udziałem 13,8\% plasowała się na miejscu trzecim. Drugą pozycję w globalnej wartości produkcji zajmowała z kolei gubernia piotrkowska, skupiając $14,9 \%$ produkcji, a w ogólnym zatrudnieniu z udziałem $16,6 \%$ zakłady ziemiańskie $\mathrm{w}$ tej guberni plasowały się na trzecim miejscu. Wśród pozostałych na uwagę zasługuje gubernia siedlecka, która pod względem udziału w ogólnej liczbie zakładów zajmowała trzecią pozycję (13,2\%), a w globalnej wartości produkcji czwartą (11,8\%). Gubernia radomska wyróżniała się jedynie znacznym udziałem w ogólnym zatrudnieniu (13,6\%), co dawało jej czwarte miejsce. Podobnie jak w 1904 r., najniższy udział we wszystkich wskaźnikach posiadały gubernie kielecka i suwalska (tab. 5 i 6). 
W latach 1879-1913 w strukturze przestrzennej przemysłu ziemiańskiego w Królestwie Polskim pierwszoplanową rolę odgrywała gubernia lubelska. Udział tej guberni $\mathrm{w}$ globalnej wartości produkcji przemysłu ziemiańskiego zwiększył się w tym czasie z 21,1\% do 26,8\%, a w zatrudnieniu z 11,7\% do 21,9\%. Jedynie w ogólnej liczbie zakładów ziemiańskich nastąpił zdecydowany spadek udziału z 25,9\% do 17,6\% (tab. 3 i 6).

\section{Rozwój przemysłu ziemiańskiego w poszczególnych guberniach Królestwa Polskiego}

W latach 1879-1913 przemysł ziemiański w guberni kaliskiej rozwijał się stosunkowo powoli. Liczba zakładów w okresie do 1904 r. zwiększyła się ponad dwukrotnie (z 26 do 63 firm), a następnie do 1913 r. spadła do 48 przedsiębiorstw. W tym czasie wartość produkcji zwiększyła się o 71\%, a liczba zatrudnionych po okresie szybkiego wzrostu o ponad 48\% w latach 1879-1900 nieco spadła w 1913 r. do 132,1\% w stosunku do 1879 r. (tab. 7).

Tabela 7. Rozwój przemysłu ziemiańskiego w guberni kaliskiej w latach 1879-1913

\begin{tabular}{|c|c|c|c|c|c|c|}
\hline Lata & Liczba firm & $\begin{array}{c}\text { Udział } \\
(\mathrm{w} \%)\end{array}$ & $\begin{array}{c}\text { Wartość produkcji } \\
\text { (w tys. rb) }\end{array}$ & $\begin{array}{c}\text { Udział } \\
(\mathrm{w} \%)\end{array}$ & $\begin{array}{c}\text { Liczba } \\
\text { robotników }\end{array}$ & $\begin{array}{c}\text { Udział } \\
(\mathrm{w} \%)\end{array}$ \\
\hline 1879 & 26 & 100,0 & 1580 & 100,0 & 818 & 100,0 \\
1900 & 50 & 192,3 & 2677 & 169,4 & 1217 & 148,7 \\
1904 & 63 & 242,3 & 2419 & 153,1 & 1076 & 131,5 \\
1913 & 48 & 184,6 & 2702 & 171,0 & 1081 & 132,1 \\
\hline
\end{tabular}

Źródło: jak w tab. 1.

Kolejną sprawą jest udział przemysłu ziemiańskiego guberni kaliskiej w całym przemyśle tej guberni. Jak wiadomo, gubernia kaliska należała do regionów, w których funkcjonowały ważne ośrodki przemysłu włókienniczego, a mianowicie Kalisz, Zduńska Wola oraz Ozorków.

Tabela 8. Udział przemysłu ziemiańskiego guberni kaliskiej w produkcji i zatrudnieniu całego przemysłu tej guberni w latach 1879-1913

\begin{tabular}{|c|c|c|c|c|c|c|}
\hline Lata & $\begin{array}{c}\text { Wartość produkcji } \\
\text { przemysłu } \\
\text { guberni kaliskiej } \\
\text { (w tys. rb) }\end{array}$ & $\begin{array}{c}\text { Wartość produkcji } \\
\text { przemysłu } \\
\text { ziemiańskiego } \\
\text { (w tys. rb) }\end{array}$ & $\begin{array}{c}\text { Udział } \\
\text { (w \%) }\end{array}$ & $\begin{array}{c}\text { Liczba } \\
\text { robotników } \\
\text { przemysłu } \\
\text { guberni kaliskiej }\end{array}$ & $\begin{array}{c}\text { Liczba } \\
\text { robotników } \\
\text { przemysłu } \\
\text { ziemiańskiego }\end{array}$ & $\begin{array}{c}\text { Udział } \\
\text { (w \%) }\end{array}$ \\
\hline 1879 & 3632 & 1580 & 43,5 & 2157 & 818 & 37,9 \\
1900 & 11938 & 2677 & 22,4 & 11679 & 1217 & 10,4 \\
1904 & 14594 & 2419 & 16,5 & 8781 & 1076 & 12,2 \\
1913 & 21568 & 2702 & 12,5 & 11630 & 1081 & 9,3 \\
\hline
\end{tabular}

Źródło: jak w tab. 1. 
Przemysł ziemiański w guberni kaliskiej w 1879 r. odgrywał istotną rolę w całym przemyśle tej guberni, bowiem skupiał $43,5 \%$ globalnej wartości produkcji przemysłowej na tym obszarze oraz prawie 38\% ogólnego zatrudnienia. Jednak w latach następnych udział zakładów ziemiańskich w produkcji oraz ogólnej liczbie robotników wyraźnie malał - w 1913 r. w globalnej wartości produkcji przemysłu całej guberni było to jedynie 12,5\%, a w zatrudnieniu 9,3\% (tab. 8). Tak więc w produkcji spadek udziału był zdecydowanie ponad trzykrotny, a w ogólnej liczbie robotników ponad czterokrotny.

Rozwój przemysłu ziemiańskiego w guberni kieleckiej przebiegał nieco odmiennie, aniżeli $\mathrm{w}$ kaliskiej. $\mathrm{W}$ poważnym stopniu decydowały o tym warunki naturalne, bowiem w guberni kieleckiej rozwijał się głównie przemysł górniczy, hutniczy, metalowy i mineralny. Otóż liczba zakładów ziemiańskich w tej guberni, po wzroście w latach 1879-1900 z 30 do 40 firm, w następnych latach wyraźnie spadła do 32 przedsiębiorstw w 1913 r. Natomiast wartość produkcji systematycznie rosła w latach 1879-1913 o ponad 179\%. Z kolei liczba robotników systematycznie w tym czasie malała o ponad $21 \%$ (tab. 9). Ten spadek liczby robotników na tym obszarze związany był z wyraźnym ograniczaniem na początku XX w. wydobycia rud żelaza w staropolskim okręgu przemysłowym (Puś 1997: 128, tab. 21).

Tabela 9. Rozwój przemysłu ziemiańskiego w guberni kieleckiej w latach 1879-1913

\begin{tabular}{|c|c|c|c|c|c|c|}
\hline Lata & Liczba firm & $\begin{array}{c}\text { Udział } \\
(\mathrm{w} \%)\end{array}$ & $\begin{array}{c}\text { Wartość produkcji } \\
\text { (w tys. rb) }\end{array}$ & $\begin{array}{c}\text { Udział } \\
(\mathrm{w} \%)\end{array}$ & $\begin{array}{c}\text { Liczba } \\
\text { robotników }\end{array}$ & $\begin{array}{c}\text { Udział } \\
(\mathrm{w} \%)\end{array}$ \\
\hline 1879 & 30 & 100,0 & 312 & 100,0 & 666 & 100,0 \\
1900 & 40 & 133,3 & 806 & 258,3 & 584 & 87,6 \\
1904 & 36 & 120,0 & 798 & 255,7 & 569 & 85,4 \\
1913 & 32 & 106,6 & 873 & 279,8 & 522 & 78,4 \\
\hline
\end{tabular}

Źródło: jak w tab. 1.

Przemysł ziemiański guberni kieleckiej, podobnie jak w wypadku guberni kaliskiej, odgrywał dość istotną rolę w produkcji i zatrudnieniu całego przemysłu tej guberni. Udział przemysłu ziemiańskiego w globalnej wartości produkcji całego przemysłu guberni kieleckiej w 1879 r. sięgał prawie $25 \%$, a w ogólnym zatrudnieniu zdecydowanie więcej - 38,4\%. W latach późniejszych, kiedy nastąpił szybki rozwój przemysłu w ośrodkach miejskich, udział ten wyraźnie się zmniejszał. I tak w 1900 r. zakłady ziemiańskie skupiały 14,3\% wartości produkcji tej guberni, a w ogólnej liczbie robotników tylko 13,1\%. W 1904 r. z kolei nieco wzrósł udział przemysłu ziemiańskiego $\mathrm{w}$ globalnej wartości produkcji do 15\%, a w ogólnym zatrudnieniu do 13,4\%. Ostatecznie w 1913 r. wskaźniki procentowe udziału zakładów ziemiańskich w produkcji oraz ogólnej liczbie robot- 
ników przemysłu guberni kieleckiej zdecydowanie się obniżyły. W globalnej wartości produkcji udział przemysłu ziemiańskiego wyniósł 8,3\%, a $\mathrm{w}$ ogólnym zatrudnieniu $\mathrm{w}$ całym przemyśle guberni osiągnął tylko 8,1\% (tab. 10). Spadek ten, jak już wspomniano, wynikał, z jednej strony, z szybszego rozwoju przemysłu w ośrodkach miejskich, z drugiej - był rezultatem wyraźnej stagnacji zakładów przemysłowych w majątkach ziemian i właścicieli ziemskich.

Warto dodać, że w latach 1879-1913 udział przemysłu ziemiańskiego guberni kieleckiej w globalnej wartości produkcji całego przemysłu tej guberni zmniejszył się trzykrotnie, a w zatrudnieniu prawie pięciokrotnie (tab. 10).

Tabela 10. Udział przemysłu ziemiańskiego guberni kieleckiej w produkcji i zatrudnieniu przemysłu tej guberni w latach 1879-1913

\begin{tabular}{|c|c|c|c|c|c|c|}
\hline Lata & $\begin{array}{c}\text { Wartość produkcji } \\
\text { przemysłu } \\
\text { guberni } \\
\text { kieleckiej) } \\
\text { (w tys. rb) }\end{array}$ & $\begin{array}{c}\text { Wartość produkcji } \\
\text { przemysłu } \\
\text { ziemiańskiego } \\
\text { (w tys. rb) }\end{array}$ & $\begin{array}{c}\text { Udział } \\
(\mathrm{w} \%)\end{array}$ & $\begin{array}{c}\text { Liczba } \\
\text { robotników } \\
\text { przemysłu } \\
\text { guberni } \\
\text { kieleckiej }\end{array}$ & $\begin{array}{c}\text { Liczba } \\
\text { robotników } \\
\text { przemysłu } \\
\text { ziemiańskiego }\end{array}$ & $\begin{array}{c}\text { Udział } \\
(\mathrm{w} \%)\end{array}$ \\
\hline 1879 & 1249 & 312 & 24,9 & 1734 & 666 & 38,4 \\
1900 & 5610 & 806 & 14,3 & 4457 & 584 & 13,1 \\
1904 & 5305 & 798 & 15,0 & 4246 & 569 & 13,4 \\
1913 & 10517 & 873 & 8,3 & 6475 & 522 & 8,1 \\
\hline
\end{tabular}

Źródło: jak w tab. 1.

W guberni lubelskiej w latach 1879-1913 nastąił dynamiczny rozwój produkcji i zatrudnienia w przemyśle ziemiańskim. Liczba zakładów, poza 1900 r., pozostawała na niezmiennym poziomie.

Tabela 11. Rozwój przemysłu ziemiańskiego guberni lubelskiej w latach 1879-1913

\begin{tabular}{|c|c|c|c|c|c|c|}
\hline Lata & Liczba firm & $\begin{array}{c}\text { Udział } \\
(\mathrm{w} \%)\end{array}$ & $\begin{array}{c}\text { Wartość produkcji } \\
\text { (w tys. rb) }\end{array}$ & $\begin{array}{c}\text { Udział } \\
(\mathrm{w} \%)\end{array}$ & $\begin{array}{c}\text { Liczba } \\
\text { robotników }\end{array}$ & $\begin{array}{c}\text { Udział } \\
(\mathrm{w} \%)\end{array}$ \\
\hline 1879 & 87 & 100,0 & 1601 & 100,0 & 1300 & 100,0 \\
1900 & 57 & 65,5 & 5897 & 368,3 & 2814 & 216,4 \\
1904 & 82 & 94,2 & 6922 & 432,3 & 2584 & 198,7 \\
1913 & 88 & 101,1 & 8277 & 516,9 & 3657 & 281,3 \\
\hline
\end{tabular}

Źródło: jak w tab. 1.

Wartość produkcji przemysłu ziemiańskiego guberni lubelskiej wzrosła w latach 1879-1913 ponad pięciokrotnie, a liczba robotników o ponad 181\% (tab. 11). Ten dynamiczny rozwój produkcji i zatrudnienia w zakładach ziemiańskich $\mathrm{w}$ guberni lubelskiej decydował o roli przemysłu ziemiańskiego $\mathrm{w}$ całym przemyśle tego obszaru. Zakłady ziemiańskie 
w latach 1879-1913 skupiały od 45,6\% do 24,9\% globalnej wartości produkcji całego przemysłu guberni lubelskiej. Podobnie w ogólnym zatrudnieniu ich udział kształtował się na wysokim poziomie (od 38,6\% do $25 \%$ ). $\mathrm{Na}$ temat roli przemysłu ziemiańskiego na Lubelszczyźnie pisał. B. Mikulec (1989). W okresie do końca XIX w. zakłady ziemiańskie w poważnym stopniu decydowały o procesie uprzemysłowienia tej guberni. Jak wspomniano, gubernia lubelska odgrywała w interesującym nas okresie szczególną rolę w przemyśle ziemiańskim Królestwa Polskiego. W latach 1879-1913 przemysł ziemiański tej guberni skupiał od 21,4\% do 26,8\% globalnej wartości produkcji oraz od 11,7\% do 21,9\% ogólnego zatrudnienia przemysłu ziemiańskiego w Królestwie (tab. 3 i 6).

Tabela 12. Udział przemysłu ziemiańskiego guberni lubelskiej w produkcji i zatrudnieniu przemysłu tej guberni w latach 1879-1913

\begin{tabular}{|c|c|c|c|c|c|c|}
\hline Lata & $\begin{array}{c}\text { Wartość produkcji } \\
\text { przemysłu } \\
\text { guberni lubelskiej } \\
\text { (w tys. rb) }\end{array}$ & $\begin{array}{c}\text { Wartość produkcji } \\
\text { przemysłu zie- } \\
\text { miańskiego } \\
\text { (w tys. rb) }\end{array}$ & $\begin{array}{c}\text { Udział } \\
\text { (w \%) }\end{array}$ & $\begin{array}{c}\text { Liczba } \\
\text { robotników } \\
\text { przemysłu } \\
\text { guberni } \\
\text { lubelskiej }\end{array}$ & $\begin{array}{c}\text { Liczba } \\
\text { robotników } \\
\text { przemysłu } \\
\text { ziemiańskiego }\end{array}$ & $\begin{array}{c}\text { Udział } \\
\text { (w \%) }\end{array}$ \\
\hline 1879 & 3775 & 1601 & 42,4 & 4125 & 1300 & 31,5 \\
1900 & 12915 & 5897 & 45,6 & 7214 & 2784 & 38,6 \\
1904 & 16414 & 6922 & 42,2 & 8830 & 2584 & 29,2 \\
1913 & 33116 & 8277 & 24,9 & 14598 & 3657 & 25,0 \\
\hline
\end{tabular}

Źródło: jak w tab. 1.

Rozwój przemysłu ziemiańskiego w guberni łomżyńskiej w latach 1879-1913 był jeszcze bardziej dynamiczny, aniżeli w guberni lubelskiej. Liczba zakładów ziemiańskich w tym czasie zwiększyła się o ponad $40 \%$ z 27 do 38 firm. Globalna wartość produkcji zakładów ziemiańskich guberni łomżyńskiej wzrosła niemal sześciokrotnie (z 309 tys. rb do 1790 tys. rb.). Podobnie dynamiczny był przyrost liczby robotników w przemyśle ziemiańskim tej guberni, w latach 1879-1913 ich liczba zwiększyła się z 210 do 783 osób, a więc prawie czterokrotnie, a w 1904 r. wzrost ten był jeszcze wyższy i sięgał $445,7 \%$ (tab. 13).

Tabela 13. Rozwój przemysłu ziemiańskiego guberni łomżyńskiej w latach 1879-1913

\begin{tabular}{|c|c|c|c|c|c|c|}
\hline Lata & Liczba firm & $\begin{array}{c}\text { Udział } \\
(\mathrm{w} \%)\end{array}$ & $\begin{array}{c}\text { Wartość produkcji } \\
\text { (w tys. rb) }\end{array}$ & $\begin{array}{c}\text { Udział } \\
(\mathrm{w} \%)\end{array}$ & $\begin{array}{c}\text { Liczba } \\
\text { robotników }\end{array}$ & $\begin{array}{c}\text { Udział } \\
(\mathrm{w} \%)\end{array}$ \\
\hline 1879 & 27 & 100,0 & 309 & 100,0 & 210 & 100,0 \\
1900 & 42 & 155,5 & 936 & 302,9 & 660 & 314,2 \\
1904 & 38 & 140,7 & 1620 & 524,2 & 936 & 445,7 \\
1913 & 38 & 140,7 & 1790 & 579,2 & 783 & 372,8 \\
\hline
\end{tabular}

Źródło: jak w tab. 1. 
Przemysł ziemiański guberni łomżyńskiej odgrywał decydującą rolę w całym przemyśle tej guberni. W latach 1879-1913 udział zakładów ziemiańskich $\mathrm{w}$ globalnej wartości produkcji przemysłu guberni łomżyńskiej wahał się od $36,3 \%$ do $58,9 \%$, a w ogólnym zatrudnieniu od $26,2 \%$ do $56,7 \%$ (tab. 14 ).

Tabela 14. Udział przemysłu ziemiańskiego guberni łomżyńskiej w produkcji i zatrudnieniu przemysłu tej guberni w latach 1879-1913

\begin{tabular}{|c|c|c|c|c|c|c|}
\hline Lata & $\begin{array}{c}\text { Wartość produkcji } \\
\text { przemysłu } \\
\text { guberni } \\
\text { łomżyńskiej } \\
\text { (w tys. rb) }\end{array}$ & $\begin{array}{c}\text { Wartość produkcji } \\
\text { przemysłu } \\
\text { ziemiańskiego } \\
\text { (w tys. rb) }\end{array}$ & $\begin{array}{c}\text { Udział } \\
(\mathrm{w} \%)\end{array}$ & $\begin{array}{c}\text { Liczba } \\
\text { robotników } \\
\text { przemysłu } \\
\text { guberni } \\
\text { łomżyńskiej }\end{array}$ & $\begin{array}{c}\text { Liczba } \\
\text { robotników } \\
\text { przemysłu } \\
\text { ziemiańskiego }\end{array}$ & $\begin{array}{c}\text { Udział } \\
(\mathrm{w} \%)\end{array}$ \\
\hline 1879 & 631 & 309 & 48,9 & 370 & 210 & 56,7 \\
1900 & 2580 & 936 & 36,3 & 2518 & 660 & 26,2 \\
1904 & 2747 & 1620 & 58,9 & 2449 & 936 & 38,2 \\
1913 & 3757 & 1790 & 47,6 & 2092 & 783 & 37,4 \\
\hline
\end{tabular}

Źródło: jak w tab. 1.

Dynamiczny rozwój przemysłu ziemiańskiego w guberni łomżyńskiej oraz decydująca rola zakładów ziemiańskich w procesie uprzemysłowienia tej typowo rolniczej guberni niestety nie szły w parze $\mathrm{z}$ ich rolą $\mathrm{w}$ przemyśle ziemiańskim Królestwa Polskiego. Otóż w latach 1879-1913 zakłady ziemiańskie guberni łomżyńskiej skupiały zaledwie od 4,1\% do 5,8\% globalnej wartości produkcji oraz od 1,9\% do 4,7\% ogólnego zatrudnienia przemysłu ziemiańskiego Królestwa Polskiego (tab. 3 i 6).

Tempo rozwoju przemysłu ziemiańskiego w guberni piotrkowskiej było zdecydowanie niższe. Liczba zakładów zwiększyła się do 1904 r. ponad trzykrotnie (z 23 do 72 firm), a następnie spadła do 45 przedsiębiorstw. Wartość produkcji wzrosła do 1904 r. zdecydowanie ponad czterokrotnie, a w 1913 r. nieco ponad czterokrotnie. Z kolei ogólne zatrudnienie zwiększyło się o ponad $60 \%$ (tab. 15 ).

Tabela 15. Rozwój przemysłu ziemiańskiego guberni piotrkowskiej w latach 1879-1913

\begin{tabular}{|c|c|c|c|c|c|c|}
\hline Lata & Liczba firm & $\begin{array}{c}\text { Udział } \\
\text { (w \%) }\end{array}$ & $\begin{array}{c}\text { Wartość produkcji } \\
\text { (w tys. rb) }\end{array}$ & $\begin{array}{c}\text { Udział } \\
\text { (w \%) }\end{array}$ & $\begin{array}{c}\text { Liczba } \\
\text { robotników }\end{array}$ & $\begin{array}{c}\text { Udział } \\
\text { (w \%) }\end{array}$ \\
\hline 1879 & 23 & 100,0 & 1145 & 100,0 & 1709 & 100,0 \\
1900 & 57 & 247,8 & 2842 & 248,2 & 1900 & 111,1 \\
1904 & 72 & 313,0 & 5040 & 440,1 & 2758 & 161,3 \\
1913 & 45 & 195,6 & 4588 & 400,6 & 2741 & 160,3 \\
\hline
\end{tabular}

Źródło: jak w tab. 1. 
Przemysł ziemiański w guberni piotrkowskiej, w odróżnieniu od guberni lubelskiej i łomżyńskiej, nie odgrywał istotnej roli w procesie uprzemysłowienia tego obszaru. W latach 1879-1913 udział zakładów ziemiańskich $\mathrm{w}$ globalnej wartości produkcji całego przemysłu guberni piotrkowskiej wahał się od 1,9\% do $0,9 \%$, a w ogólnym zatrudnieniu od $4,5 \%$ do $1,2 \%$ (tab. 16). Tak minimalny udział przemysłu ziemiańskiego w produkcji i ogólnej liczbie robotników całego przemysłu tej guberni był związany z funkcjonowaniem na jej obszarze dwóch największych okręgów przemysłowych Królestwa Polskiego, łódzkiego i sosnowiecko-częstochowskiego. Rozwój przemysłu włókienniczego w regionie łódzkim oraz sosnowiecko-częstochowskim, jak również przemysłu górniczo-hutniczego i metalowego w Zagłębiu Dąbrowskim doprowadziły do powstania wielkich (Łódź) i dużych (Częstochowa, Sosnowiec, Pabianice) ośrodków miejskich, które decydowały o procesie industrializacji na tym obszarze. Natomiast przemysł ziemiański w tym procesie nie odgrywał istotnej roli, stanowił jedynie uzupełnienie dochodów niektórych majątków ziemiańskich.

Tabela 16. Udział przemysłu ziemiańskiego guberni piotrkowskiej w produkcji i zatrudnieniu przemysłu tej guberni w latach 1879-1913

\begin{tabular}{|c|c|c|c|c|c|c|}
\hline Lata & $\begin{array}{c}\text { Wartość produkcji } \\
\text { przemysłu } \\
\text { guberni } \\
\text { piotrkowskiej } \\
\text { (w tys. rb) }\end{array}$ & $\begin{array}{c}\text { Wartość produkcji } \\
\text { przemysłu } \\
\text { ziemiańskiego } \\
\text { (w tys. rb) }\end{array}$ & $\begin{array}{c}\text { Udział } \\
(\mathrm{w} \%)\end{array}$ & $\begin{array}{c}\text { Liczba } \\
\text { robotników } \\
\text { przemysłu } \\
\text { guberni } \\
\text { piotrkowskiej }\end{array}$ & $\begin{array}{c}\text { Liczba } \\
\text { robotników } \\
\text { przemysłu } \\
\text { ziemiańskiego }\end{array}$ & $\begin{array}{c}\text { Udział } \\
(\mathrm{w} \%)\end{array}$ \\
\hline 1879 & 59949 & 1145 & 1,9 & 38101 & 1709 & 4,5 \\
1900 & 232559 & 2842 & 1,2 & 140819 & 1900 & 1,3 \\
1904 & 352630 & 5040 & 1,4 & 183762 & 2758 & 1,5 \\
1913 & 503639 & 4588 & 0,9 & 226463 & 2741 & 1,2 \\
\hline
\end{tabular}

Źródło: jak w tab. 1.

Przemysł ziemiański guberni piotrkowskiej w latach 1879-1913 stanowił od $12,6 \%$ do $18,5 \%$ globalnej wartości produkcji oraz od $14,1 \%$ do 18,2\% ogólnej liczby robotników przemysłu ziemiańskiego Królestwa Polskiego (tab. 3 i 6 ).

Rozwój przemysłu ziemiańskiego w kolejnej, typowo rolniczej guberni płockiej, był bardzo powolny. W latach 1879-1913 liczba zakładów ziemiańskich zwiększyła się jedynie z 18 do 22 firm.

Wzrost wartości produkcji był zdecydowanie wyższy i w 1904 r. przekroczył 370\% w stosunku do 1879 r., a w 1913 r. dość wyraźnie spadł, osiągając 302,1\%. Podobnie w ogólnej liczbie robotników, jedynie w 1904 r. wystąpił przyrost zatrudnienia o 9,9\% w stosunku do 1879 r., a już w 1913 r. nastąpił spadek poniżej poziomu z 1879 r. o 3,1\% (tab. 17). 
Mimo stosunkowo powolnego tempa rozwoju przemysłu ziemiańskiego $\mathrm{w}$ guberni płockiej, firmy ziemiańskie odgrywały poważną rolę $\mathrm{w}$ procesie uprzemysłowienia tej guberni (tab. 18).

Tabela 17. Rozwój przemysłu ziemiańskiego w guberni płockiej w latach 1879-1913

\begin{tabular}{|c|c|c|c|c|c|r|}
\hline Lata & Liczba firm & $\begin{array}{c}\text { Udział } \\
(\mathrm{w} \%)\end{array}$ & $\begin{array}{c}\text { Wartość produkcji } \\
\text { (w tys. rb) }\end{array}$ & $\begin{array}{c}\text { Udział } \\
(\mathrm{w} \%)\end{array}$ & $\begin{array}{c}\text { Liczba } \\
\text { robotników }\end{array}$ & $\begin{array}{r}\text { Udział } \\
(\mathrm{w} \%)\end{array}$ \\
\hline 1879 & 18 & 100,0 & 508 & 100,0 & 695 & 100,0 \\
1900 & 14 & 77,7 & 1048 & 206,2 & 465 & 66,9 \\
1904 & 21 & 116,6 & 1880 & 370,0 & 764 & 109,9 \\
1913 & 22 & 122,2 & 1535 & 302,1 & 674 & 96,9 \\
\hline
\end{tabular}

Źródło: jak w tab. 1.

Tabela 18. Udział przemysłu ziemiańskiego guberni płockiej w produkcji i zatrudnieniu przemysłu tej guberni w latach 1879-1913

\begin{tabular}{|c|c|c|c|c|c|c|}
\hline Lata & $\begin{array}{c}\text { Wartość produkcji } \\
\text { przemysłu } \\
\text { guberni płockiej } \\
\text { (w tys. rb) }\end{array}$ & $\begin{array}{c}\text { Wartość produkcji } \\
\text { przemysłu } \\
\text { ziemiańskiego }\end{array}$ & $\begin{array}{c}\text { Udział } \\
(\mathrm{w} \%)\end{array}$ & $\begin{array}{c}\text { Liczba } \\
\text { robotników } \\
\text { przemysłu } \\
\text { guberni } \\
\text { płockiej }\end{array}$ & $\begin{array}{c}\text { Liczba } \\
\text { robotników } \\
\text { przemysłu } \\
\text { ziemiańskiego }\end{array}$ & $\begin{array}{c}\text { Udział } \\
(\mathrm{w} \%)\end{array}$ \\
\hline 1879 & 1371 & 508 & 37,0 & 1444 & 695 & 48,1 \\
1900 & 4033 & 1048 & 25,9 & 2089 & 465 & 22,2 \\
1904 & 6246 & 1880 & 30,0 & 3081 & 764 & 24,7 \\
1913 & 9256 & 1535 & 16,6 & 3858 & 674 & 17,4 \\
\hline
\end{tabular}

Źródło: jak w tab. 1.

W 1879 r. wartość produkcji zakładów ziemiańskich stanowiła 37\% globalnej wartości produkcji całego przemysłu guberni płockiej, a w zatrudnieniu udział ten był jeszcze wyższy i sięgał ponad $48 \%$ ogólnej liczby robotników tej guberni. W końcu badanego okresu wskaźniki te uległy wyraźnej zmianie, ale w dalszym ciągu w 1913 r. przemysł ziemiański skupiał 16,6\% globalnej produkcji oraz 17,4\% ogólnego zatrudnienia (tab. 18). W całym przemyśle ziemiańskim Królestwa Polskiego firmy ziemiańskie guberni płockiej skupiały w latach 1879-1913 zaledwie od 6,7\% do 4,9\% globalnej wartości produkcji oraz od 6,3\% do 4\% ogólnej liczby robotników (tab. 3 i 6).

W guberni radomskiej, w której granicach znajdował się (w większej części) staropolski okręg przemysłowy, przemysł ziemiański związany z wydobyciem rudy żelaza oraz hutnictwem rozwijał się do $1904 \mathrm{r}$. dość dynamicznie, a w okresie do 1913 r. proces ten został wyraźnie zahamowany. $W$ tym czasie liczba zakładów ziemiańskich zwiększyła się z 48 w 1879 r. do 80 w 1904 r., a następnie w 1913 r. spadła do 51 
firm. Natomiast wartość produkcji przemysłu ziemiańskiego tej guberni w szybkim tempie rosła, do 1900 r. osiągając wskaźnik 555,5\%, a następnie już w 1904 r. zdecydowanie spadła do poziomu 360,5\% w stosunku do 1879 r. W 1913 r. nastąpił ponowny, ponad czterokrotny, wzrost do 438,7\% (tab. 19). Z kolei ogólna liczba robotników w przemyśle ziemiańskim tej guberni systematycznie się zmniejszała do 1913 r. niemal o 30\% (tab. 19). Wyraźne zahamowanie rozwoju przemysłu ziemiańskiego w guberni radomskiej na początku XX w. należy wyjaśnić coraz mniejszym popytem na rudę żelaza niskiej jakości oraz upadkiem wielu małych, niemodernizowanych zakładów hutniczych i metalowych w okręgu staropolskim. Jak wiadomo, nowoczesne zakłady hutnicze w Królestwie Polskim w tym czasie korzystały z wysokogatunkowej rudy krzyworoskiej, przywożonej z Rosji (Pazdur 1961: 81; Jezierski 1967: 135-136).

Tabela 19. Rozwój przemysłu ziemiańskiego w guberni radomskiej w latach 1879-1913

\begin{tabular}{|c|c|c|c|c|c|r|}
\hline Lata & Liczba firm & $\begin{array}{c}\text { Udział } \\
(\mathrm{w} \%)\end{array}$ & $\begin{array}{c}\text { Wartość produkcji } \\
\text { (w tys. rb) }\end{array}$ & $\begin{array}{c}\text { Udział } \\
(\mathrm{w} \%)\end{array}$ & $\begin{array}{c}\text { Liczba } \\
\text { robotników }\end{array}$ & $\begin{array}{c}\text { Udział } \\
(\mathrm{w} \%)\end{array}$ \\
\hline 1879 & 48 & 100,0 & 616 & 100,0 & 3157 & 100,0 \\
1900 & 56 & 116,6 & 3422 & 555,5 & 2610 & 82,6 \\
1904 & 80 & 166,6 & 2221 & 360,5 & 3024 & 95,7 \\
1913 & 51 & 106,2 & 2703 & 438,7 & 2249 & 71,2 \\
\hline
\end{tabular}

Źródło: jak w tab. 1.

Rola przemysłu ziemiańskiego guberni radomskiej w całym przemyśle tej guberni była stosunkowo niewielka. Rozwijający się przemysł $\mathrm{w}$ ośrodkach miejskich tej guberni zdecydowanie wyprzedzał tempo wzrostu produkcji i zatrudnienia $\mathrm{w}$ zakładach ziemiańskich. W 1879 r. udział przemysłu ziemiańskiego w globalnej wartości produkcji przemysłowej całej guberni radomskiej wynosił 9,5\%, w $1900 \mathrm{r}$. wskaźnik ten wzrósł do 13,8\%, a następnie systematycznie spadał w 1904 r. było to 8,6\%, a w 1913 r. już tylko 6,6\%. W 1879 r. zakłady ziemiańskie skupiały $37 \%$ ogółu robotników zatrudnionych w tej guberni, ale w latach następnych udział ten wyraźnie spadał i w $1913 \mathrm{r}$. osiągnął wskaźnik 9,2\% (tab. 20). Mimo dość znacznej roli tej guberni, szczególnie pod względem zatrudnienia, przemysł ziemiański systematycznie tracił znaczenie. W całym przemyśle ziemiańskim Królestwa Polskiego zakłady ziemiańskie w guberni radomskiej w latach 1879-1913 skupiały od 14,4\% do 10,1\% ogólnej liczby firm, 8,1\% do $8,7 \%$ globalnej wartości produkcji oraz od 28,4\% do 13,6\% ogólnego zatrudnienia (tab. 3 i 6 ). 
Przemysł ziemiański w Królestwie Polskim w latach 1879-1913

Tabela 20. Udział przemysłu ziemiańskiego guberni radomskiej w produkcji i zatrudnieniu przemysłu tej guberni w latach 1879-1913

\begin{tabular}{|c|c|c|c|c|c|c|}
\hline Lata & $\begin{array}{c}\text { Wartość produkcji } \\
\text { przemysłu } \\
\text { guberni } \\
\text { radomskiej } \\
\text { (w tys. rb) }\end{array}$ & $\begin{array}{c}\text { Wartość produkcji } \\
\text { przemysłu } \\
\text { ziemiańskiego }\end{array}$ & $\begin{array}{c}\text { Udział } \\
(\mathrm{w} \%)\end{array}$ & $\begin{array}{c}\text { Liczba } \\
\text { robotników } \\
\text { przemysłu } \\
\text { guberni ra- } \\
\text { domskiej }\end{array}$ & $\begin{array}{c}\text { Liczba } \\
\text { robotników } \\
\text { przemysłu } \\
\text { ziemiańskiego }\end{array}$ & $\begin{array}{c}\text { Udział } \\
(\mathrm{w} \%)\end{array}$ \\
\hline 1879 & 6479 & 616 & 9,5 & 8558 & 3167 & 37,0 \\
1900 & 24665 & 3422 & 13,8 & 18326 & 2605 & 14,2 \\
1904 & 25543 & 2221 & 8,7 & 19630 & 3024 & 15,4 \\
1913 & 40515 & 2703 & 6,6 & 24401 & 2249 & 9,2 \\
\hline
\end{tabular}

Źródło: jak w tab. 1.

W kolejnej guberni typowo rolniczej, jaką była gubernia siedlecka, rozwój przemysłu ziemiańskiego był w latach 1879-1913 dość dynamiczny. Liczba zakładów w tym czasie wzrosła już w 1900 r. prawie o 30\% i na tym poziomie pozostała do $1913 \mathrm{r}$. Natomiast wartość produkcji przemysłu ziemiańskiego zwiększyła się ponad czterokrotnie (z 834 tys. rb do 3 mln 647 tys. rb.). Z kolei liczba robotników od 1879 r. do 1904 r. wzrosła o ponad 81\%, a w 1913 r. nastąpił zdecydowany spadek (o ponad 50\%) w stosunku do 1849 i wyniósł 1325 osób. Spadek ten był następstwem wstrzymania produkcji w hucie szkła Czechy w miejscowości Trąbki, która została sprzedana przez dotychczasowych właścicieli - rodzinę Hordliczków (PH za 1913, nr 3294).

Tabela 21. Rozwój przemysłu ziemiańskiego w guberni siedleckiej w latach 1879-1913

\begin{tabular}{|c|c|c|c|c|c|c|}
\hline Lata & Liczba firm & $\begin{array}{c}\text { Udział } \\
(\mathrm{w} \%)\end{array}$ & $\begin{array}{c}\text { Wartość produkcji } \\
\text { (w tys. rb) }\end{array}$ & $\begin{array}{c}\text { Udział } \\
(\mathrm{w} \%)\end{array}$ & $\begin{array}{c}\text { Liczba } \\
\text { robotników }\end{array}$ & $\begin{array}{c}\text { Udział } \\
(\mathrm{w} \%)\end{array}$ \\
\hline 1879 & 51 & 100,0 & 834 & 100,0 & 1018 & 100,0 \\
1900 & 66 & 129,4 & 2200 & 263,7 & 1659 & 162,9 \\
1904 & 67 & 131,3 & 2920 & 350,1 & 1849 & 181,6 \\
1913 & 66 & 129,4 & 3647 & 437,2 & 1325 & 130,1 \\
\hline
\end{tabular}

Źródło: jak w tab. 1.

Przemysł ziemiański guberni siedleckiej odgrywał bardzo poważną rolę w procesie uprzemysłowienia tej guberni. W latach 1879-1913 udział zakładów ziemiańskich w globalnej wartości produkcji całego przemysłu guberni siedleckiej kształtował się na poziomie od 74,6\% do 57,4\%. W ogólnym zatrudnieniu firmy ziemiańskie skupiały od 74,3\% w 1879 r. do 38,8\% w 1913 r. ogółu robotników pracujących w przemyśle tej guberni (tab. 22). Firmy ziemiańskie guberni siedleckiej odgrywały istotną rolę w całym przemyśle ziemiańskim Królestwa Polskiego. W latach 1879-1913 
skupiały one od 15,3\% do 13,2\% ogółu zakładów, od 11\% do 11,8\% globalnej wartości produkcji oraz od 9,2\% do $8 \%$ ogólnego zatrudnienia w przemyśle ziemiańskim Królestwa Polskiego (tab. 3 i 6).

Tabela 22. Udział przemysłu ziemiańskiego guberni siedleckiej w produkcji i zatrudnieniu przemysłu tej guberni w latach 1879-1913

\begin{tabular}{|c|c|c|c|c|c|c|}
\hline Lata & $\begin{array}{c}\text { Wartość produkcji } \\
\text { przemysłu } \\
\text { guberni } \\
\text { siedleckiej } \\
\text { (w tys. rb) }\end{array}$ & $\begin{array}{c}\text { Wartość produkcji } \\
\text { przemysłu } \\
\text { ziemiańskiego }\end{array}$ & $\begin{array}{c}\text { Udział } \\
(\mathrm{w} \%)\end{array}$ & $\begin{array}{c}\text { Liczba } \\
\text { robotników } \\
\text { przemysłu } \\
\text { guberni sie- } \\
\text { dleckiej }\end{array}$ & $\begin{array}{c}\text { Liczba } \\
\text { robotników } \\
\text { przemysłu } \\
\text { ziemiańskiego }\end{array}$ & $\begin{array}{c}\text { Udział } \\
(\mathrm{w} \%)\end{array}$ \\
\hline 1879 & 1118 & 834 & 74,6 & 1370 & 1018 & 74,3 \\
1900 & 3052 & 2200 & 72,1 & 2925 & 1659 & 56,7 \\
1904 & 4521 & 2920 & 64,6 & 4037 & 1849 & 45,8 \\
1913 & 6346 & 3647 & 57,4 & 3411 & 1325 & 38,8 \\
\hline
\end{tabular}

Źródło: jak w tab. 1.

Przemysł ziemiański guberni suwalskiej, którego udział w całym przemyśle ziemiańskim Królestwa Polskiego w latach 1879-1913 był najniższy ze wszystkich guberni, rozwijał się bardzo dynamicznie. Liczba zakładów zwiększyła się ponad dwukrotnie (z 9 do 24 firm), wartość produkcji wzrosła ponad sześć i pół razy (z 85 tys. rb do 562 tys. rb), podobnie liczba zatrudnionych (z 55 do 359 osób - tab. 23).

Tabela 23. Rozwój przemysłu ziemiańskiego w guberni suwalskiej w latach 1879-1913

\begin{tabular}{|c|c|c|c|c|c|c|}
\hline Lata & Liczba firm & $\begin{array}{c}\text { Udział } \\
\text { (w \%) }\end{array}$ & $\begin{array}{c}\text { Wartość produkcji } \\
\text { (w tys. rb) }\end{array}$ & $\begin{array}{c}\text { Udział } \\
\text { (w \%) }\end{array}$ & $\begin{array}{c}\text { Liczba } \\
\text { robotników }\end{array}$ & $\begin{array}{c}\text { Udział } \\
\text { (w \%) }\end{array}$ \\
\hline 1879 & 9 & 100,0 & 85 & 100,0 & 55 & 100,0 \\
1900 & 21 & 233,3 & 414 & 487,0 & 195 & 354,5 \\
1904 & 21 & 233,3 & 285 & 335,2 & 178 & 323,6 \\
1913 & 24 & 266,6 & 562 & 661,1 & 359 & 652,7 \\
\hline
\end{tabular}

Źródło: jak w tab. 1.

Przemysł ziemiański w guberni suwalskiej, będącej obszarem typowo rolniczym, odgrywał ważną rolę w całym przemyśle tej guberni. W latach 1879-1913 udział zakładów ziemiańskich w globalnej wartości produkcji całego przemysłu guberni suwalskiej kształtował się na poziomie od 11,8\% w 1904 r. do $24 \%$ w 1900 r. Natomiast w ogólnym zatrudnieniu w przemyśle guberni suwalskiej firmy ziemiańskie skupiały od $14,5 \%$ w 1879 r. do 22,5\% w 1913 r. ogólnej liczby robotników (tab.24).

Jak już wspomniano, zakłady ziemiańskie guberni suwalskiej miały niewielki udział w przemyśle Królestwa Polskiego. W latach 1879-1913 udział ten w ogólnej liczbie zakładów kształtował się na poziomie od 2,7\% 
do $4,8 \%$, w globalnej wartości produkcji od 1,1\% do 1,8\%, a w ogólnym zatrudnieniu od $0,5 \%$ do $2,1 \%$ (tab. 3 i 6 ).

Tabela 24. Udział przemysłu ziemiańskiego guberni suwalskiej w produkcji i zatrudnieniu przemysłu tej guberni w latach 1879-1913

\begin{tabular}{|c|c|c|c|c|c|c|}
\hline Lata & $\begin{array}{c}\text { Wartość produkcji } \\
\text { przemysłu } \\
\text { guberni } \\
\text { suwalskiej } \\
\text { (w tys. rb) }\end{array}$ & $\begin{array}{c}\text { Wartość produkcji } \\
\text { przemysłu } \\
\text { ziemiańskiego }\end{array}$ & $\begin{array}{c}\text { Udział } \\
(\mathrm{w} \%)\end{array}$ & $\begin{array}{c}\text { Liczba } \\
\text { robotników } \\
\text { przemysłu } \\
\text { guberni } \\
\text { suwalskiej }\end{array}$ & $\begin{array}{c}\text { Liczba } \\
\text { robotników } \\
\text { przemysłu } \\
\text { ziemiańskiego }\end{array}$ & $\begin{array}{c}\text { Udział } \\
(\mathrm{w} \%)\end{array}$ \\
\hline 1879 & 424 & 85 & 20,0 & 377 & 55 & 14,5 \\
1900 & 1718 & 414 & 24,0 & 1017 & 195 & 19,1 \\
1904 & 2416 & 285 & 11,8 & 1096 & 178 & 16,2 \\
1913 & 3132 & 562 & 17,9 & 1594 & 359 & 22,5 \\
\hline
\end{tabular}

Źródło: jak w tab. 1.

W guberni warszawskiej rozwój przemysłu ziemiańskiego był bardzo dynamiczny, w latach 1879-1913 liczba zakładów zwiększyła się ponad pięciokrotnie (z 16 do 87 przedsiębiorstw). Z kolei wartość produkcji przemysłu ziemiańskiego $\mathrm{w}$ tej guberni wzrosła ponad siedmiokrotnie (z 590 tys. rb do 4 mln 269 tys. rb.). Liczba robotników w tym czasie zwiększyła się ponad dwukrotnie z 1468 do 3252 osób (tab. 25).

Tabela 25. Rozwój przemysłu ziemiańskiego w guberni warszawskiej w latach 1879-1913

\begin{tabular}{|c|c|c|c|c|c|r|}
\hline Lata & Liczba firm & $\begin{array}{c}\text { Udział } \\
(\mathrm{w} \%)\end{array}$ & $\begin{array}{c}\text { Wartość produkcji } \\
\text { (w tys. rb) }\end{array}$ & $\begin{array}{c}\text { Udział } \\
(\mathrm{w} \%)\end{array}$ & $\begin{array}{c}\text { Liczba } \\
\text { robotników }\end{array}$ & $\begin{array}{c}\text { Udział } \\
(\mathrm{w} \%)\end{array}$ \\
\hline 1879 & 16 & 100,0 & 590 & 100,0 & 1468 & 100,0 \\
1900 & 68 & 425,0 & 2498 & 423,3 & 1392 & 94,8 \\
1904 & 78 & 487,5 & 3174 & 537,9 & 1424 & 97,0 \\
1913 & 87 & 543,7 & 4269 & 723,5 & 3252 & 221,5 \\
\hline
\end{tabular}

Źródło: jak w tab. 1.

Tabela 26. Udział przemysłu ziemiańskiego guberni warszawskiej w produkcji i zatrudnieniu przemysłu tej guberni w latach 1879-1913

\begin{tabular}{|c|c|c|c|c|c|c|}
\hline Lata & $\begin{array}{c}\text { Wartość produkcji } \\
\text { przemysłu } \\
\text { guberni } \\
\text { warszawskiej } \\
\text { (w tys. rb) }\end{array}$ & $\begin{array}{c}\text { Wartość produkcji } \\
\text { przemysłu } \\
\text { ziemiańskiego }\end{array}$ & $\begin{array}{c}\text { Udział } \\
(\mathrm{w} \%)\end{array}$ & $\begin{array}{c}\text { Liczba } \\
\text { robotników } \\
\text { przemysłu } \\
\text { guberni } \\
\text { warszawskiej }\end{array}$ & $\begin{array}{c}\text { Liczba } \\
\text { robotników } \\
\text { przemysłu } \\
\text { ziemiańskiego }\end{array}$ & $\begin{array}{c}\text { Udział } \\
(\mathrm{w} \%)\end{array}$ \\
\hline 1879 & 37465 & 590 & 1,6 & 31567 & 1468 & 4,6 \\
1900 & 106305 & 2497 & 2,3 & 63087 & 1392 & 2,2 \\
1904 & 162929 & 3174 & 1,9 & 85365 & 1424 & 1,6 \\
1913 & 258097 & 4269 & 1,6 & 113776 & 3252 & 2,8 \\
\hline
\end{tabular}

Źródło: jak w tab. 1. 
Udział przemysłu ziemiańskiego w globalnej produkcji całego przemysłu guberni warszawskiej był minimalny, w latach 1879-1913 kształtował się na poziomie od 1,6\% do 2,3\%. W ogólnym zatrudnieniu sytuacja była podobna, najniższy wskaźnik udziału w 1904 r. wynosił 1,6\%, a najwyższy w 1879 r. 4,6\% (tab. 26). Niewielkie znaczenie przemysłu ziemiańskiego w guberni warszawskiej było następstwem funkcjonowania na tym obszarze silnie uprzemysłowionego ośrodka, jakim była Warszawa oraz warszawskiego okręgu przemysłowego (Puś 1997: 108-112; Pruss 1977). Przemysł ziemiański guberni warszawskiej w latach 1879-1914 zdecydowanie zwiększył swój udział w całym przemyśle ziemiańskim w Królestwie Polskim. Udział w ogólnej liczbie zakładów wzrósł w tym czasie z 4,8\% do 17,3\%, w globalnej wartości produkcji z 7,8\% do 13,8\%, a w zatrudnieniu z 13,2\% do $19,5 \%$ (tab. 3 i 6 ).

$* * *$

Kończąc rozważania na temat rozwoju przemysłu ziemiańskiego w Królestwie Polskim oraz jego struktury przestrzennej, warto podjąć próbę określenia stosunku liczby zakładów ziemiańskich do liczby dóbr 254 lub właścicieli dóbr ziemskich na tym obszarze. Po raz pierwszy w literaturze podjęła taką próbę R. Chomać-Klimek (1979), która na podstawie danych statystycznych odnoszących się do dóbr ziemskich obciążonych pożyczkami Towarzystwa Kredytowego Ziemskiego za lata 1879 i 1892 podała liczbę zakładów przemysłowych funkcjonujących w tych dobrach. Otóż w 1879 r. na ogólną liczbę 7625 majątków stowarzyszonych funkcjonowało według tych danych 4429 zakładów przemysłowych, a więc ponad 58\% majątków (trzeba jednak pamiętać, że w wielu majątkach ziemskich mogły funkcjonować dwa lub więcej zakładów przemysłowych). Natomiast w 1892 r. na ogólną liczbę 9000 dóbr przypadało 3535 zakładów przemysłowych, co stanowiło ponad 39\% majątków (Chomać-Klimek 1979: 69-77). Należy dodać, że cytowane dane statystyczne obejmują wszystkie zakłady, które funkcjonowały w dobrach ziemskich bez względu na ich wielkość, mierzoną choćby poprzez liczbę zatrudnionych robotników. W prezentowanym artykule bierzemy pod uwagę jedynie zakłady zatrudniające od 5 robotników wzwyż, a wyjątkowo w wypadku gorzelni, tartaków i młynów także te, które zatrudniały 4 robotników. Wydaje się więc, że dane statystyczne, którymi posługiwała się R. Chomać-Klimek, obejmowały wszystkie zakłady produkcji pozarolniczej, które funkcjonowały w dobrach ziemskich w Królestwie Polskim, także i te zatrudniające 1, 2 lub 3 robotników. W większości były to różnego typu przyfolwarczne zakłady przetwórstwa płodów rolnych, raczej nie mające 
zbyt wiele wspólnego z przemysłem. Przy okazji autorka przywoływanego artykułu, powołując się na dane statystyczne W. Załęskiego i S. Koszutskiego, stwierdza, że zakłady przemysłowe funkcjonujące w majątkach ziemskich w 1879 r. stanowiły od 25-50\% liczby wszystkich firm przemysłowych w Królestwie Polskim (Chomać-Klimek 1979: 70). Otóż należy przypomnieć, że dane W. Załęskiego za 1873 r. (13 917 zakładów) pochodziły z informacji, które publikowano w tzw. Obzorach poszczególnych guberni, gdzie nie oddzielano przemysłu od rzemiosła. Podobnie dane S. Koszutskiego za 1882 r. (7060 zakładów) obejmują wszystkie firmy bez względu na wielkość zatrudnienia (Załęski 1876: 235; Koszutski 1901: 167; zob. porównanie statystyki Obzorów z danymi pochodzącymi ze spisów i skorowidzów Orłowa i Warzara - Puś 1976).

Liczba zakładów przemysłowych funkcjonujących w dobrach stowarzyszonych w TKZ za 1879 r., którą podaje R. Chomać-Klimek, zdecydowanie przekracza liczbę wszystkich firm przemysłowych w Królestwie Polskim. Otóż w 1879 r. w całym przemyśle Królestwa Polskiego - licząc zakłady przemysłowe zatrudniające od 5 robotników wzwyż - funkcjonowało 1922 przedsiębiorstw, a tymczasem wg statystyki TKZ w majątkach ziemskich było 4429 firm. Z kolei w 1893 r. w Królestwie Polskim liczba wszystkich zakładów przemysłowych wynosiła 2788, a wg statystyki TKZ tylko w majątkach ziemskich funkcjonowało ich 3535 (Puś 2013: 9, tab. 1). Tak więc dane te są nieporównywalne.

W. Caban, pisząc o uprzemysłowieniu majątków ziemskich w guberni radomskiej na przełomie lat 50. i 60. XIX w., wskazał, że jedynie 6,6\% właścicieli majątków w tej guberni „prowadziło działania w kwestii uprzemysłowienia". Przy okazji autor podał informację na temat liczebności właścicieli ziemskich na przełomie lat 50. i 60. XIX w. w Królestwie Polskim wg danych z raportu N. Milutina. Otóż w tym czasie w Królestwie Polskim było 7200 właścicieli majątków ziemskich (Caban 2010: 10).

Niezwykle trudno jest dokładnie określić liczbę właścicieli ziemskich lub liczbę dóbr ziemskich (jak bowiem wiadomo, niekiedy jeden właściciel posiadał kilka lub więcej dóbr). Jeśli przyjmiemy dla 1879 r. liczbę dóbr stowarzyszonych w TKZ, która wynosiła 7625 majątków, to według naszych danych dotyczących liczby zakładów przemysłowych ziemiańskich, których było 336, ich udział w ogólnej liczbie majątków stanowił zaledwie 4,4\%. Dla $1900 \mathrm{r}$. w przybliżeniu możemy przyjąć liczbę 9000 majątków, a zakładów przemysłowych ziemiańskich 471, to ich udział w ogólnej liczbie dóbr wynosił 5,23\%. Według danych statystycznych, w 1913 r. było 9778 dóbr stowarzyszonych w Królestwie Polskim. Z naszych badań wynika, że zakładów przemysłowych ziemiańskich zatrudniających 5 robotników i więcej funkcjonowało 501, co dawało 5,12\% w stosunku do ogółu majątków ziemskich (dane dotyczące liczby dóbr 
za: Krzyżanowski, Kumaniecki 1915: 170, tab. 172). Powyższe informacje na temat procentowego udziału ziemiańskich zakładów przemysłowych w ogólnej liczbie dóbr ziemskich są zbliżone do wspomnianych już danych W. Cabana, które odnosiły się do guberni radomskiej w okresie przeduwłaszczeniowym, kiedy to jedynie 6,6\% właścicieli ziemskich angażowało się $\mathrm{w}$ uprzemysłowienie swoich dóbr. Wszystko to potwierdza znaną już tezę o stosunkowo niewielkiej aktywności ziemiaństwa Królestwa Polskiego w procesie industrializacji w okresie do $1914 \mathrm{r}$.

\section{Literatura}

Caban W. (2010), O potrzebie badań nad udziałem ziemiaństwa Królestwa Polskiego doby przeduwłaszczeniowej $w$ działaniach na rzecz rozwoju przemystu, "Studia z Historii Społeczno-Gospodarczej XIX i XX wieku", t. 8.

Chomać-Klimek R. (1979), Sprawa uprzemysłowienia majątków ziemskich Królestwa Polskiego $w$ drugiej połowie XIX w., „Acta Universitatis Lodziensis”, Folia Historica, Ser. I, nr 43, s. 69-77.

Jezierski A. (1967), Handel zagraniczny Królestwa Polskiego 1815-1914, Warszawa.

Koszutski S. (1901), Rozwój przemystu wielkiego w Królestwie Polskim, Warszawa.

Krzyżanowski A., Kumaniecki K. (1915), Statystyka Polski, Kraków.

Mikulec B. (1989), Przemyst Lubelszczyzny w latach 1864-1914, Lublin.

Pazdur J. (1961), Górnictwo rud żelaza, [w:] J. Pazdur (red.), Zarys dziejów górnictwa na ziemiach polskich, Katowice.

Pruss W. (1977), Rozwój przemystu warszawskiego w latach 1864-1914, Warszawa.

Puś W. (1976), Przemyst włókienniczy w Królestwie Polskim w latach 1870-1900. Zagadnienia struktury i dynamiki rozwoju, Łódź.

Puś W. (1997), Rozwój przemystu w Królestwie Polskim, Łódź.

Puś W. (2013), Statystyka przemystu Królestwa Polskiego w latach 1879-1913. Materiały źródłowe, Łódź.

Załęski W. (1876), Statystyka porównawcza Królestwa Polskiego, Warszawa.

Wiesław Puś, prof. dr hab.,

Katedra Historii Społeczno-Gospodarczej, Instytut Historii, Wydział Filozoficzno-Historyczny,

Uniwersytet Łódzki 